\title{
Pengembangan Bahan Ajar Berbasis Lingkungan Sekitar Pada Siswa Kelas IV Sekolah Dasar
}

\section{Development of Environmental Based Teaching Materials in Grade IV Students Elementary School}

\author{
Hasnawati \\ Institut Agama Islam Negeri (IAIN) Palopo \\ Email:hasnawatipgmi@gmail.com
}

Received:22-01-2020

Accepted:20-04-2020

Published:06-06-2020

\author{
How to cite this article: \\ Hasnawati. (2020). Pengembangan Bahan Ajar Berbasis Lingkungan Sekitar Pada Siswa \\ Kelas VI Sekolah Dasar. Pedagogik Journal of Islamic Elementary School, 3(1), 119- \\ 134. https://doi.org/10.24256/pijies.v3i1.1134
}

\begin{abstract}
Research aims to find out how avalid and effective environment-based teaching material is designed. This research is a research method of researchEDevelopment (RED). To develop the product, this research follows the design of 4-D developmentmodel that includes four phases: Define, Design, Develop, Disseminate. The trial subjects were 18 students in class IV SDIT Al-Bashirah city Palopo. The results of the validity of the design teaching book are obtained by the value 4.18 with valid categories. The effectiveness of teaching materials is analyzed based onthe results of student study test and studen response after testing conducted. Theresults of the test analysis obtained anaverage of 79.16 good categories with a percentage of $89 \%$. While the results of the student responses poll analysis obtained $81.29 \%$ of students respond positively to teaching materials. The analysis was concluded that the neighbourhood-based teaching book wasincluded in the criteria for the validity and effectiveness of the teaching materials.
\end{abstract}

Keywords: Elementary School; Environment; Teaching Materials Development.

\begin{abstract}
Abstrak
Penelitian bertujuan untuk mengetahui bagaimana rancangan bahan ajar berbasis lingkungan sekitar yang valid dan efektif. Penelitian ini merupakan metode penelitian Research $\mathcal{E}$ Development(RED). Untuk mengembangkan produk, penelitian ini mengikuti desain model pengembangan 4-D yang meliputi empat tahapan yakni: Define, Design, Develop, Disseminate. Subjek uji coba adalah 18 orang siswa pada kelas IV SDIT AlBashirah Kota Palopo. Hasil analisis validitas rancangan buku ajar diperoleh nilai 4.18 dengan kategori valid. Adapun keefektifan bahan ajar dianalisis berdasarkan hasil tes belajar siswa dan respon siswa setelah ujicoba dilakukan. Hasil analisis tes diperoleh rata-rata 79,16 kategori baik dengan persentase ketuntasan 89\%. Sedangkan hasil analisis angket respon PiJIES:Pedagogik Journal of Islamic Elementary School
\end{abstract}


siswa diperoleh nilai $81,29 \%$ siswa merespon positif bahan ajar. Dari hasil analisis tersebut disimpulkan bahwa buku ajar berbasis lingkungan sekitar telah termasuk dalam kriteria validitas dan efektifitas bahan ajar.

Kata kunci: sekolah dasar, lingkungan sekitar; pengembangan bahan ajar.

(CPedagogik Journal of Islamic Elementary School. This is an open access article under

the Creative Commons - Attribution-ShareAlike 4.0 International license (CC BY-SA 4.0)

\section{Pendahuluan}

Salah satu factor pendukung keberhasilan pendidikan ialah seorang pendidik diwajibkan mampu mengembangkan bahan ajar agar proses pembelajaran berhasil. Bahan ajar merupakan suatu perangkat pembelajaran baik berbentuk cetak maupun non cetak yang dibutuhkan oleh seorang pendidik untuk meningkatkan proses pembelajaran (Daryanto \& Aris, 2014).

Dalam kegiatan belajar mengajar tidak hanya pendidik dan siswa saja yang terlibat tetapi melibatkan berbagai pihak seperti bahan ajar yang sangat dibutuhkan yang mengarahkan pada proses pembelajaran yang berlangsung. Bahan ajar yang baik yaitu bisa membuat siswa mudah paham kepada materi yang disampaikan oleh guru dan dapat merangsang siswa membangun pengetahuan yang didapat. Menggunakan bahan ajar, siswa akan belajar secara sistematis, terstruktur, dan terarah sehingga mampu menguasai pembelajaran secara utuh dan terpadu (Hidayati, 2016).

Hasil observasi awal yang peneliti lakukan pada 21 April 2018 di kelas IV SDIT Al-Bashirah Kota Palopo, belum tersedianya bahan ajar Ilmu Pengetahuan Alam (IPA) tentang materi sumber daya alam berbasis lingkungan sekitar dimana guru dalam menyampaikan materi masih berpatokan ke buku cetak berisi uraian materi secara umum tanpa adanya pengembangan berkaitan dengan kehidupan atau lingkungan sekitar siswa secara nyata. Hal ini mengakibatkan dalam proses pembelajaran siswa kurang berperan aktif karena siswa sulit memahami materi. Sejalan yang dikemukakan oleh Puspita (2017) bahwa saat ini di seluruh Indonesia di sekolah-sekolah menggunakan bahan ajar yang memuat materi secara luas, 
akibatnya siswa menjadi kurang kenal denga lingkungan terdekatnya. Materi yang terlalu luas akan membuat tujuan yang sudah dirancang tidak dapat tercapai, disebabkan karaktersitik siswa yang masih berada pada tahap perkembangan operational konkret belum siap menerima materi dalam lingkup global.

Menurut Hidayati (2016) mengembangkan materi ajar harus disesuikan dengan tujuan pembelajaran yang telah dirumuskan. Mengembangkan bahan ajar ialah suatu kegiatan mendesain sumber belajar inovatif sebagai sumber belajar baru dari sumber belajar yang sudah ada sebelumnya, bahan ajar yang ada memiliki pembeda baik dari segi struktur maupun isi. Strukturnya bisa lebih sederhana dan spesifik pada sebuah topik isinya pun bisa lebih rinci dan mendalam serta memiliki nuansa tersendiri (Kapitan, Harsiati, \& Basuki, 2018). Untuk menghadapi isu global, siswa diharapkan mampu meningkatkan pengetahuan dan keterampilan secara vertikal dan horizontal antar mata pelajaran (Rustan, Hanifah, \& Kanro, 2018).

Pada penelitian ini peneliti mengembangkan sebuah bahan ajar berupa buku ajar pada pembelajarn IPA. Buku ajar merupakan sarana belajar untuk pendidik dan peserta didik sebagai penunjang tercapainya tujuan pembelajaran (Nurdyansyah, 2015). Ilmu Pengetahuan Alam ialah pengamatan suatu objek yang dilakukan manusia untuk mengetahui tentang alam semesta secara sistematis yang dijelaskan dengan penalaran hingga memperoleh sebuah kesimpulan (Sarti, 2019). IPA adalah ilmu yang membelajarkan tentang alam semesta dan isinya baik tentang benda maupun mahluk hidup yang diperoleh secara ilmiah.

Pembelajaran IPA merupakan mata pelajaran yang dipelajari pada semua jenjang pendidikan diantaranya pada tingkat dasar dan juga sebagai alat atau tempat sangat ampuh bagi siswa dalam mempelajari berbagai bidang ilmu lainnya. Jenjang pendidikan Sekolah Dasar atau Madrasah Ibtidaiyah masih membutuhkan arahan dan bimbingan dalam belajar. Maka dari itu belajar perlu diawali dengan masalah yang real diantaranya mengaitkan materi dengan lingkungan sekitar dekat dengan siswa (Aprilia, 2018). Lingkungan sekitar adalah bagian dari alam semesta yang dapat dijadikan sebagai sumber belajar (Istiani \& Retnoningsih, 2015). 
Dalam pembelajaran pendekatan berbasis lingkungan, siswa didorong untuk mengembangkan kompetensi yang dimiliki. Siswa terstimulasi untuk belajar penuh makna dikarenakan siswa akan belajar dari yang dekat yaitu di daerahnya. Selain itu, siswa juga dapat berperan aktif dalam belajar sehingga mampu meningkatkan hasil belajarnya. Adapun materi pokok yang digunakan dalam mengembangkan bahan ajar adalah materi tentang sumber daya alam yang merupakan semua yang berasal dari alam dapat digunakan manusia untuk mencukupi keperluan hidupnya yang tersebar diberbagai tempat seperti di hutan, laut, sungai dan gunung.

Penelitian ini disesuaikan dengan tahap-tahap siklus pengembangan yang terdiri dari beberapa tahap yakni: melakukan kajian mengenai temuan penelitian produk kemudian dikembangkan menjadi sebuah produk, yang selanjutnya akan diuji cobakan (Setyosari, 2013). Tujuan dari penelitian adalah untuk mengetahui bagaimana rancangan bahan ajar berbasis lingkungan sekitar yang valid dan untuk mengetahui tingkat keefektifan bahan ajar yang dikembangkan.

\section{Metode}

Penelitian ini merupakan jenis penelitian Research $\mathcal{E}$ Development (RED) dengan pendekatan mixed-method. Untuk mengembangkan produk berupa buku ajar, peneliti mengikuti 4D models Thiangarajan dalam (Al-Tabani, 2017) yang melalui beberapa tahapan yakni; Define (pendefenisian), Design (perancangan), Develop (pengembangan), dan Disseminate (penyebaran). Subjek uji coba adalah siswa yang berjumlah 18 orang pada kelas IV. Data dikumpulkan menggunakan lembar validasi, tes, dan angket respons siswa. Adapun yang dianalisis adalah: 1. Kevalidan bahan ajar yang dianalisis secara kuantitatif. 2. Keefektifan bahan ajar dinilai dari hasil belajar dan persentase respon siswa yang dianalisis secara kuantitatif dengan pendekatan statistik desktiptif.

\section{Hasil Penelitian}

Rancangan Bahan Ajar Materi Sumber Daya Alam Berbasis Lingkungan Sekitar.

\section{PiJIES: Pedagogik Journal of Islamic Elementary School}


Rancangan/desain buku ajar berbasis lingkungan sekitar mengikuti desain pengembangan 4-D models yang meliputi beberapa tahapan yang perlu dilakukan yakni, pendefenisian, perancangan, pengembangan, dan penyebaran. Tahap penyebaran belum bisa dilaksanakan dikarenakan keterbatasan waktu dan biaya.

Berikut ini tahap atau struktur penjabaran komponen buku ajar berbasis lingkungan sekitar dalam pelaksanaan pembelajaran di kelas.

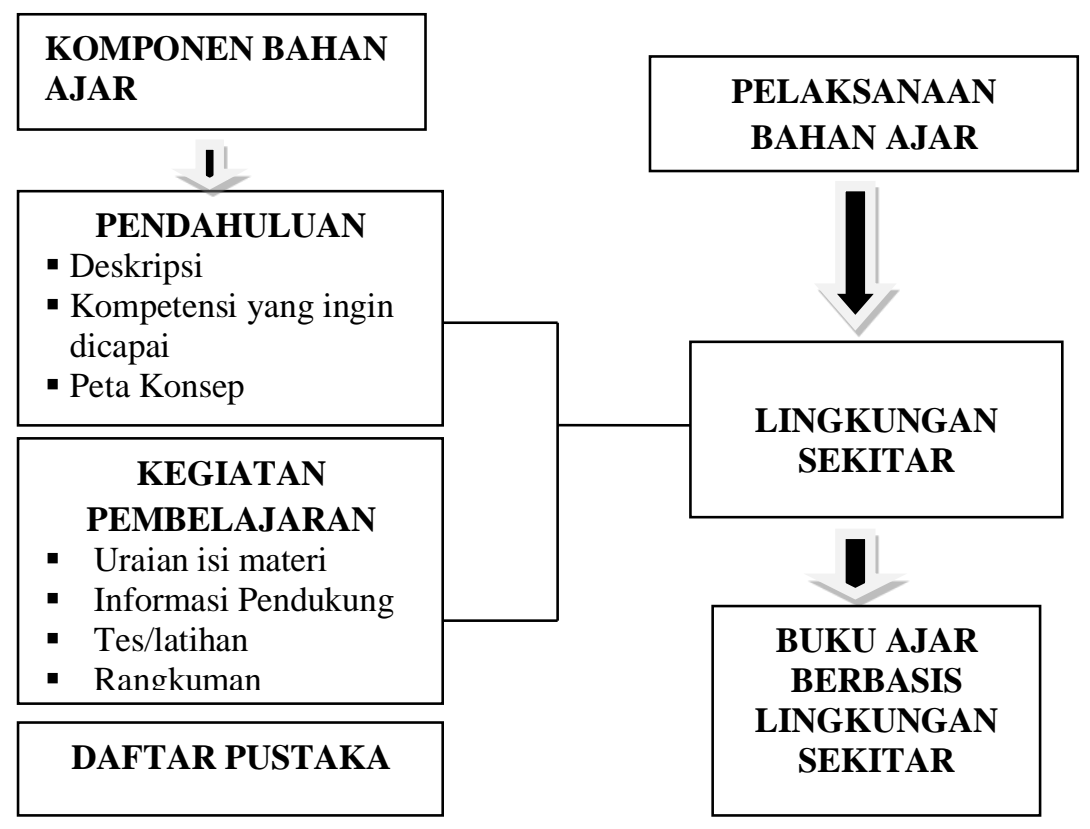

Gambar 1. Penjabaran komponen bahan ajar berbasis lingkungan sekitar

Validasi Ahli Bahan Ajar Berupa Buku Ajar Materi Sumber Daya Alam Berbasis Lingkungan Sekitar

Salah satu kriteria dalam menetapkan layak atau tidak bahan ajar untuk digunakan diperoleh dari hasil validasi para pakar. Kegiatan menvalidasi dilakukan dengan memberi buku ajar dan lembar penilaiannya kepada validator pada bidang studi yang sesuai diikuti dengan revisi berdasarkan masukan dan saran dari validator.

Berikut ini adalah format desain (prototype) bahan ajar yang telah dinyatakan valid setelah melakukan validasi dari beberapa ahli: 
1) Sampul Buku Ajar

Cover atau sampul didesain semenarik mungkin agar menarik perhatian pembaca untuk mengetahui isi di dalam buku. Dalam sampul berisi judul (buku ajar sumber daya alam berbasis lingkungan sekitar), digunakan bagi siswa kelas 4 SD/MI semester ganjil, dan nama penyusun (Hasnawati). Sampul didesain semenarik mungkin dengan memberi ilustrasi disesuaikan dengan materi serta mengaitkan materi dengan lingkungan sekitar siswa. Sejalan dengan pendapat (Priyanto, 2012) bahwa desain buku ajar yang menarik akan memotivasi serta menarik perhatian siswa untuk mempelajari dan membacanya begitu pula dengan pilihan gambar-gambar yang dekat dengan lingkungan yang mudah dikenal siswa, karena siswa akan mudah tertarik pada yang sudah mereka kenal. Sebaliknya, buku ajar dengan tampilan yang tidak menarik akan dijauhi siswa karena cenderung membuat siswa merasa bosan.
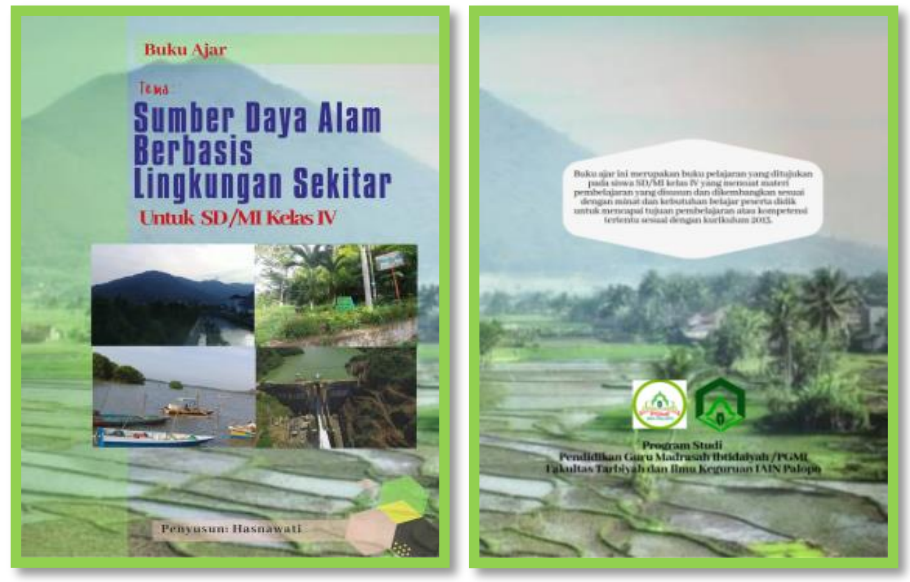

Gambar 2. Sampul BukuAjar

2) Kata Pengantar

Kata pengantar berisi rangkaian beberapa kata tentang yang melatar belakangi penyusunan bahanajar dan ucapan ditujukan kepada pihak yang terlibat selama menyusun bahan ajar.

3) Daftar Isi 
Daftar isi berisi tentang isi buku yang merujuk pada halaman untuk memudahkan pembaca mendapatkan materi yang akan dipelajari dan dibaca.

4) KD,Tujuan Pembelajaran,dan Peta Konsep

$\mathrm{KD}$, tujuan pembelajaran, peta konsep berisi tentang beberapa hal yang hendak dicapai dalam pembelajaran. Peta konsep ialah berupa bagan pemetaan konsep keseluruhan pada isi buku ajar yang dibuat peneliti untuk mempermudah siswa mengetahui secara pesifik dari isi buku ajar.

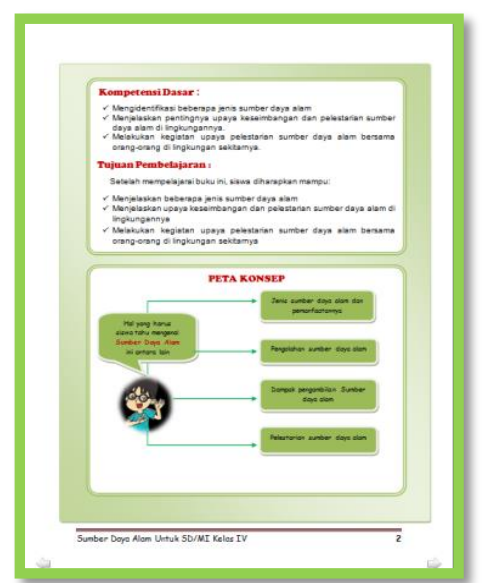

Gambar 3. KD, Tujuan Pembelajaran dan Peta Konsep

5) Pengantar Materi

Peneliti menggunakan pengantar materi dengan memberikan deskripsi awal tentang materi dengan mengajak siswa untuk mempelajari materi . 


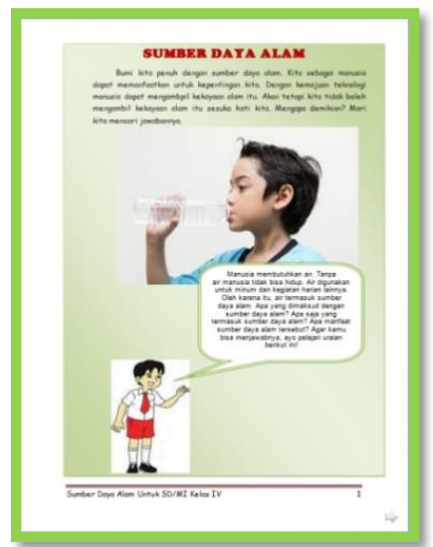

Gambar 4. Pengantar Materi

6) Isi Buku Ajar

Materi dalam buku disajikan dengan mengaitkan materi dengan lingkungan terdekat siswa, dimana setiap halaman disajikan contoh konkrit terkait dengan materi, dan pemberian ilustrasi dilengkapi dengan deskripsi gambar sesuai dengan lingkungan sekitar siswa. Sejalan dengan pendapat (Su'udiah, Degeng, \& Kuswandi, 2016) bahwa pemberian contoh baik berupa gambar maupun penjelasan (pemodelan) dalam buku ajar sebaiknya berkaitan dengan lingkungan sekitar untuk mendorong siswa mengkonsruk pengetahuanya sendiri untuk memudahkan memahami suatu materi.
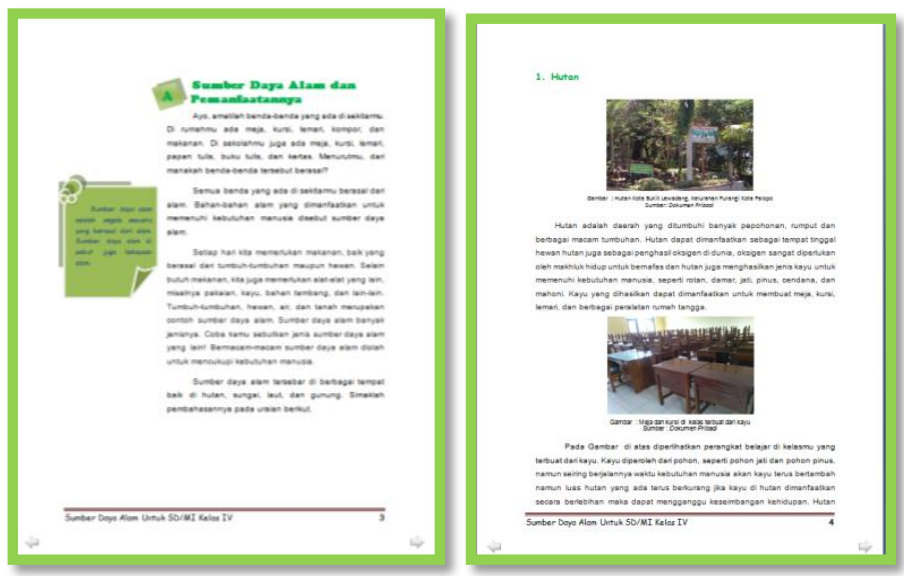

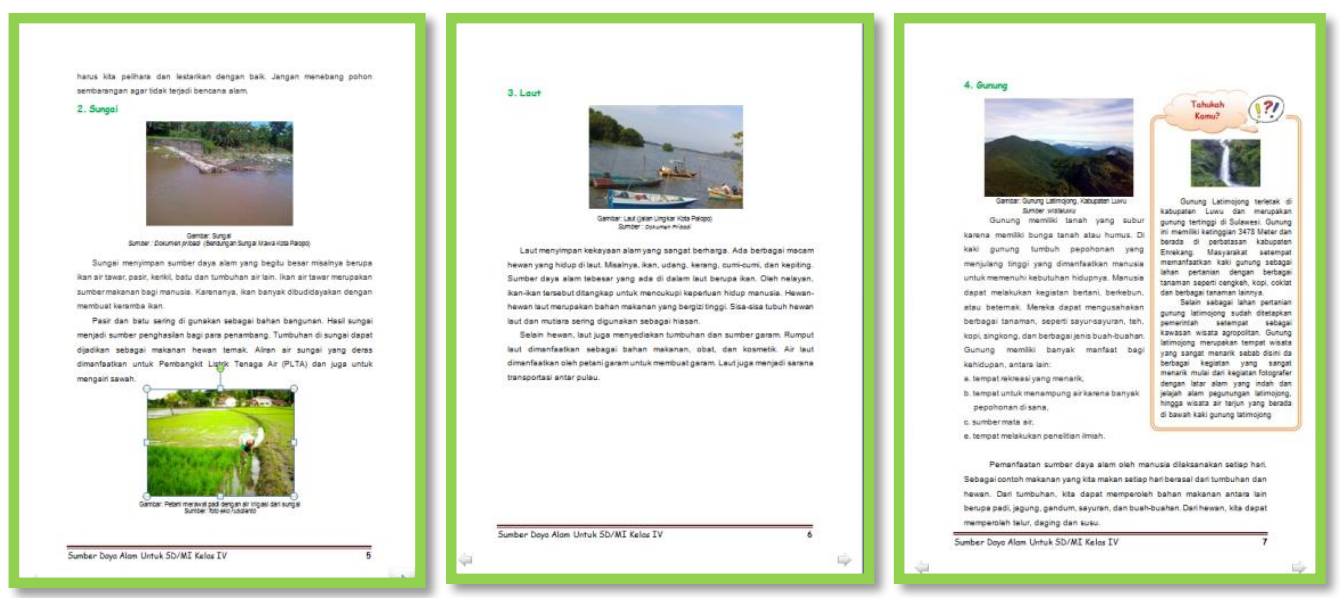

Gambar 5. Isi buku ajar

\section{7) Soal Latihan}

Soal latihan dibuat untuk melatih kemampuan siswa dalam memahami materi.

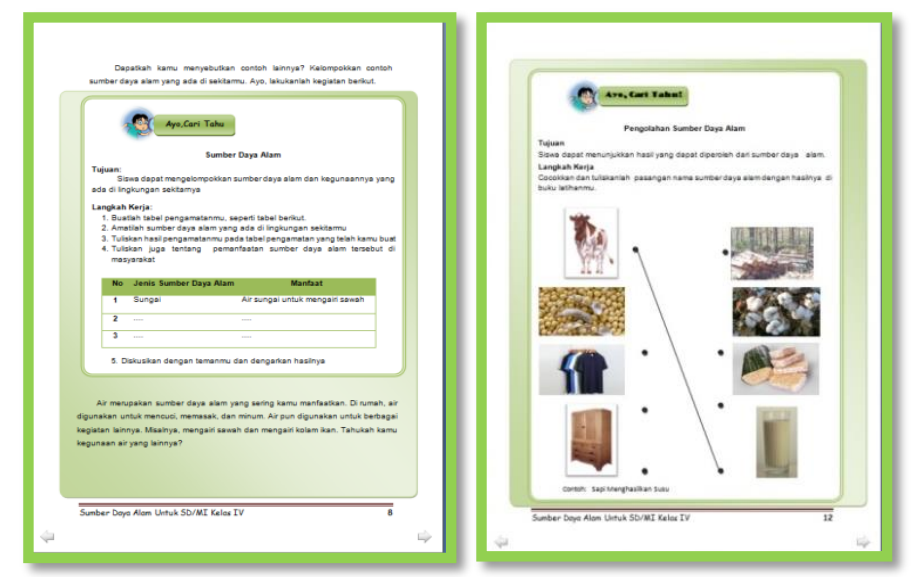

Gambar 6. Soal Latihan

8) Rangkuman

Rangkuman berisi tentang singkatan dari materi yang dijelaskan pada akhir materi di dalam buku dengan tujuan memudahkan siswa mengingat kembali materi yang telah dipelajari. 


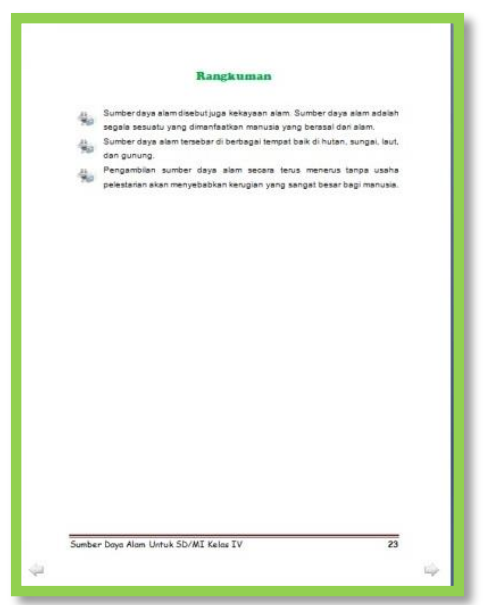

Gambar 7. Rangkuman

Keefektifan Bahan Ajar Berupa Buku Ajar Berbasis Lingkungan Sekitar Terhadap Hasil Belajar Dan Respon Siswa Terhadap Buku Ajar.

1) Hasil belajar siswa

Keefektifan dari buku ajar diperoleh dengan melihat hasil tes belajar siswa. Menurut Nasution dalam (Fannie \& Rohati, 2014) tes diberikan setelah pembelajaran dilakukan untuk mengukur sejauh mana tingkat pemahaman siswa terhadap suatu materi.

Hasil analisis statistik deskriptif penguasaan siswa terhadap materi dengan tes hasil belajar siswa kelas IV SDIT Al-Bashirah Kota Palopo menggunakan buku ajar berbasis lingkungan sekitar diperoleh hasil 89\% siswa tuntas atau mencapai nilai KKM yaitu 70. Dengan demikian, buku ajar dinyatakan efektif dalam proses pembelajaran.

\section{2) Respons Siswa}

Untuk mengukur bagaimana tanggapan siswa terhadap buku ajar digunakan angket. Dimana sebagai respondennya adalah 18 orang siswa kelas IV SDIT AlBashirah Kota Palopo. Berikut hasil analisis dari keseluruhan angket respons siswa. 
Tabel 1. Hasil analisis keseluruhan dari angket respons siswa

\begin{tabular}{rccc}
\hline No & Indikator Penilaian & Persentase $\%$ & Kategori \\
\hline 1 & Kemenarikan & $81 \%$ & Baik \\
2 & Materi & $78,47 \%$ & Baik \\
3 & Bahasa & $87 \%$ & Sangat Baik \\
\hline & Persentase keseluruhan respon siswa & $\mathbf{8 1 , 2 9 \%}$ & Sangat Baik \\
\hline
\end{tabular}

Maka diketahui bahwa buku ajar berbasis lingkungan sekitar yang di kembangkan dikatakan efektif dilihat dari hasil analisis persentase keseluruhan respon siswa diperoleh $81,29 \%$ kategori sangat baik (jika $81,25<x<100$ ).

\section{Pembahasan}

Rancangan Bahan Ajar Berupa Buku Ajar Berbasis Lingkungan Sekitar Yang Valid.

Seperti yang peneliti jelaskan pada metode, penelitian dan pengembangan ini mengikuti tahapan model 4D. Langkah pertama pengembangan bahan ajar diawali pada tahap pendefinisian yang berujuan untuk menganalisis kebutuhan yang perlu diangkat dalam mengembangankan bahan ajar. Termasuk dalam analisis ini adalah analisis kurikulum yang berlaku, analisis siswa, analisis materi,dan analisis tujuan pembelajaran.

Tahapan kedua adalah perancangan. Pada tahap ini dihasilkan rancangan awal (prototype 1) bahan ajar berupa buku ajar materi sumber daya alam berbasis lingkungan sekitar. Langkah yang dilakukan dalam tahapan diantaranya:rancangan materi, rancangan media, dan rancangan format. Dalam perancangan yang perlu dilakukan adalah memilih materi pokok disesuikan tujuan pembelajaran yang telah dirumuskan.

Pemilihan media disesuikan dengan fasilitas yang ada di sekolah dan buku ajar pokok bahasan sumber daya alam yang dikembangkan. Format bahan ajar berupa buku ajar dirancang dengan mempertimbangkan keefesienan dan keefektifannya. Sumber materi berasal dari buku guru dan buku siswa pembelajaran tematik untuk kelas IV SD, tema 3 (peduli trhadap makluk hidup),subtema 1 pembelajaran 1 edisi 2017,serta referensi dari internet. 
Tahapan selanjutnya pengembangan, dalam tahap ini diperoleh bentuk akhir buku ajar (prototype 2) yang valid setelah direvisi dengan mempertimbangkan kritik dan saran dari validator. Tahap ini meliputi validasi bahan ajar dan uji coba terbatas. Kegiatan menvalidasi buku ajar diawali dengan meminta para ahli untuk menvalidasi bahan ajar yang dihasilkan.

Tingkat Kevalidan Bahan Ajar Berupa Buku Ajar Berbasis Lingkungan Sekitar.

Sebelum digunakan di lapangan peneliti terlebih dahulu melakukan validasi. Validitas bahan ajar berupa buku ajar berbasis lingkungan sekitar diuji oleh tiga orang validator yang ahli pada bidang pendidikan. Validasi bahan ajar dilaksanakan sebanyak dua kali diikuti perbaikan berdasarkan masukan dan saran dari validator dengan tujuan menilai kualitas dan kelayakan bahan ajar untuk selanjutnya diujicobakan. Aspek-aspek yang divalidasi pada bahan ajar berbasis lingkungan sekitar adalah aspek isi, kontruksi, kebahasaan, dan kegrafisan. Hasil uji validasi ini kemudian dihitung nilai kelayakan bahan ajarnya.

Suatu bahan ajar dinyatakan valid apabila telah konsisten dalam setiap penyusunan bagian-bagian buku ajar yang biasa disebut sebagai validitas konstruk (Nurdin, 2010). Bahan bisa disebut valid jika tujuan pembelajaran, materi pembelajaran dan isi buku telah sesuai.

Hasil analisis secara kuantitatif dari rekapitulasi validitas buku ajar dari tiga validator diperoleh nilai 4.18. Mengacu pada kategori nilai validasi yang dikemukakan oleh Hobri (2010) nilai tersebut masuk dalam kategori baik. Instrumen dinyatakan valid apabila mencapai nilai validitas dengan interval $4 \leq \mathrm{Va}<5$ (Hobri, 2010).

Tingkat Keefektifan Bahan Ajar Berupa Buku Ajar Berbasis Lingkungan Sekitar Berdasarkan Hasil Belajar Siswa Dan Respons Siswa Terhadap Buku Ajar.

Setelah melalui tahap validasi, maka yang akan dilakukan selanjutnya adalah uji coba buku ajar. Setyosari (2013) mengemukakan bahwa suatu produk yang telah terbukti valid dapat diujicobakan. Uji coba dilakukan guna mengetahui

\section{PiJIES: Pedagogik Journal of Islamic Elementary School}


keefektifan bahan ajar yang telah dikembangkan. Sejalan dengan pendapat (Ahmad, 2005) bahwa uji coba dilakukan agar mendapatkan sebuah informasi mengenai keefektifan dan keefisienan bahan ajar.

Berdasarkan analisis data uji efektifitas dengan menggunakan analisis statistik deskriptif diperoleh hasil bahwa 89\% siswa dalam pembelajaran telah mencapai nilai KKM yaitu 70. Dapat disimpulkan bahwa buku ajar yang dikembangkan efektif dan efisien karena dengan menggunakannya hasil belajar siswa meningkat. Sedangkan untuk respons siswa terhadap bahan ajar diproleh hasil analisis persentase keseluruhan $81,29 \%$ kategori Sangat Baik.

Berdasarkan hasil ujicoba yang dilakukan menggunakan buku ajar berbasis lingkungan sekitar dari analisis diperoleh bahwa hasil belajar dan respons siswa memenuhi kriteria keefektifan. Hasil penelitian ini sejalan dengan penelitian yang dilakukan oleh Aprilia (2018) bahwa dalam mengajarkan IPA, pembelajaran hendaknya menjadi pengalaman yang menyenangkan dan mampu meningkatkan keaktifan siswa dalam belajar. Dengan demikian siswa mudah untuk memahami konsep yang sedang dipelajari dan hasil belajar yang diperoleh pun semakin baik. Hal tersebut diperkuat oleh Nurdyansyah (2015) yang mengemukakan bahwa buku ajar merupakan sarana belajar untuk pendidik dan peserta didik sebagai penunjang tercapainya tujuan pembelajaran.

\section{Kesimpulan}

Rancangan buku ajar berbasis lingkungan sekitar, didesain dengan mengikuti beberapa tahapan yakni: pendefinisian, perancangan, dan pengembangan. Hasil rekapitulasi kevalidan terhadap bahan ajar dapat diperoleh nilai 4.18 sehingga jika ditinjau dari keseluruhan aspek nilai tersebut telah memenuhi kriteria sehingga bahan ajar termasuk dalam kategori valid. Sedangkan, untuk tingkat keefektifan bahan ajar berdasarkan analisis data uji efektifitas rata-rata hasil belajar siswa setelah menggunakan buku ajar mencapai 79,16 dengan persentase ketuntasan $89 \%$ dan hasil analisis respons siswa terhadap bahan ajar 
memiliki respon positif denganpersentase 81,29\% kategori sangat baik. Maka dari itu bahan ajar yang dikembagkan dikatakan valid dan efektif dalam pembelajaran karena mampu meningkatkan hasil belajar siswa.

\section{Daftar Pustaka}

Ahmad, M. D. (2005). Validitas Konstruk Skala Afek. 2(1).

Al-Tabani, T. I. B. (2017). Mendesain Model Pembelajaran Inovatif, Progresif, dan Kontekstual: Landasan, dan Implementasinya Pada Kurikulum 2013 (Kurikulum Tematik Interaktif/KTI) (Cet. Ke-3). Jakarta: Kencana, PT Kharisma Putra Utama.

Aprilia, A. (2018). Pemahaman Konsep Perubahan Sifat Benda Pada Mata Pelajaran IPA Melalui Metode Eksperimen. Pedagogik Journal of Islamic Elementary School, 1(1), 11-22. https:/ / doi.org/10.24256/ pijies.v1i1.339

Daryanto, \& Aris, D. (2014). Pengembangan Perangkat Pembelajaran (Silabus, RPP, PHB, Bahan Ajar). Yogyakarta: Penerbit Gava Media.

Fannie, R. ., \& Rohati. (2014). Pengembangan Lembar Kerja Siswa (LKS) Berbasis POE (Predict, Observe, Explain) Pada Materi Program Linier. Jurnal Sainmatika, 8(1), 96-109.

Hidayati, N. (2016). pengembangan bahan ajar bahasa indonesia berbasis lingkungan hidup terintegrasi dalam pembelajaran membaca dan menulis teks siswa smp negeri 2 turen. $4(1), 68-80$.

Hobri. (2010). Metodologi Penelitian Pengembangan. Mangli: Pena Salsabila.

Istiani, R. M., \& Retnoningsih, A. (2015). Pemanfaatan Lingkungan Sekolah Sebagai Sumber Belajar Menggunakan Metode Post To Post Pada Materi Klasifikasi Makhluk Hidup. Journal of Biology Education, 4(1), 70-80.

Kapitan, Y. J., Harsiati, T., \& Basuki, I. A. (2018). pengembangan bahan ajar menulis teks cerita fantasi bermuatan nilai pendidikan karakter di kelas VII. Jurnal Pendidikan: Teori, Penelitian, Dan Pengembangan, 3(1), 100-106. https:// doi.org/10.17977/JPTPP.V3I1.10378

Nurdin. (2010). Model Pembelajaran Matematika Yang Menumbuhkan Kemampuan Metakognitif Untuk Menguasai Bahan Ajar.

Nurdyansyah, R. pujiana L. (2015). Pembiasaan Karakter Islam Dalam Pengembangan Buku Ajar Bahasa Jawa Piwulang 5 Pengalamanku Kelas I Mi Nurur Rohmah Jasem Sidoarjo. 35-49.

Priyanto, S. H. (2012). Kriteria Baku Buku Ajar. Disampaikan Dalam Workshop Penulisan Buku Ajar Dosen Kopertis IV, 31. 
Puspita, A. M. I. (2017). pengaruh penggunaan bahan ajar tematik berbasis lingkungan terhadap hasil belajar siswa kelas II SDN III Tanggung. STKIP PGRI Trenggalek, 3(1), 39-48.

Rustan, E., Hanifah, N., \& Kanro, B. (2018). De-radicalization in the Implementation of Islamic Education Curriculum in SMA Masamba South Sulawesi. Dinamika Ilmu, 18(2), 271-283. https:/ / doi.org/10.21093/ di.v18i2.1338

Sarti. (2019). Penerapan Model Cooperative Script Dalam Pembelajaran IPA Pokok Bahasan Gaya Untuk Meningkatkan Hasil Belajar Pada Siswa Kelas IV SDN 097 Rompu Kabupaten Luwu Utara. Pedagogik Journal of Islamic Elementary School, $1(2)$.

Setyosari, P. (2013). metode penelitian dan pengembangan (edisi. 3:).

Su'udiah, F., Degeng, I., \& Kuswandi, D. (2016). Pengembangan Buku Teks Tematik Berbasis Kontekstual. Jurnal Pendidikan - Teori, Penelitian, Dan Pengembangan, 1(9), 1744-1748. https:/ / doi.org/10.17977/jp.v1i9.6743 
Halaman ini sengaja dikosongkan 